Canadian Journal of Higher Education

Revue canadienne d'enseignement supérieur

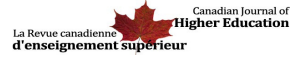

\title{
Ethno-linguistic patterns of degree completion in BC universities: How important are high-school academic achievement and institution of entry?
}

\author{
Robert Sweet, Ashley Pullman, Maria Adamuti-Trache and Karen Robson
}

Volume 49, Number 3, 2019

URI: https://id.erudit.org/iderudit/1066636ar

DOI: https://doi.org/10.7202/1066636ar

See table of contents

Publisher(s)

Canadian Society for the Study of Higher Education

ISSN

2293-6602 (digital)

Explore this journal

Cite this article

Sweet, R., Pullman, A., Adamuti-Trache, M. \& Robson, K. (2019). Ethno-linguistic patterns of degree completion in BC universities: How important are high-school academic achievement and institution of entry? Canadian Journal of Higher Education / Revue canadienne d'enseignement supérieur, 49(3), 69-87. https://doi.org/10.7202/1066636ar

\section{Article abstract}

We examine bachelor's degree completion in the British Columbia post-secondary system, which is noted for its multiple pathways to graduation and ethnically diverse student population. Employing an administrative longitudinal dataset, we compare how the probability of degree completion by students enrolled at research-intensive, teaching-intensive, and college-technical institutions differs by ethno-linguistic background and high school grades. Estimates from multi-level logistic regression

modelsdemonstrate that Korean, Tagalog, and Vietnamese speakers have lower probabilities of degree completion than English-speaking students. The type of institution a student initially enters is, however, an important correlate of degree completion for all ethno-linguistic groups. Students with lower high school grades who initially enter a research-intensive institution are more likely to graduate compared with higher-achieving students who enter a teaching-intensive or college-technical institution. To improve completion by institutional type and among ethno-linguistic groups, our study highlights the need for research on why degree completion is lower at certain institutions for all ethno-linguistic groups and consistently lower among Korean, Tagalog, and Vietnamese speakers regardless of their level of academic achievement in high school or the type of post-secondary institution they initially entered.
Copyright (c) Robert Sweet, Ashley Pullman, Maria Adamuti-Trache, Karen Robson, 2019
This document is protected by copyright law. Use of the services of Érudit (including reproduction) is subject to its terms and conditions, which can be viewed online.

https://apropos.erudit.org/en/users/policy-on-use/ 


\title{
ETHNO-LINGUISTIC PATTERNS OF DEGREE COMPLETION IN BC UNIVERSITIES: HOW IMPORTANT ARE HIGH-SCHOOL ACADEMIC ACHIEVEMENT AND INSTITUTION OF ENTRY?
}

\author{
ROBERT SWEET \\ LAKEHEAD UNIVERSITY
}

\author{
ASHLEY PULLMAN \\ UNIVERSITY OF OTTAWA
}

\author{
MARIA ADAMUTI-TRACHE \\ UNIVERSITY OF TEXAS, \\ ARLINGTON
}

\author{
KAREN ROBSON \\ MCMASTER UNIVERSITY
}

\begin{abstract}
We examine bachelor's degree completion in the British Columbia post-secondary system, which is noted for its multiple pathways to graduation and ethnically diverse student population. Employing an administrative longitudinal dataset, we compare how the probability of degree completion by students enrolled at research-intensive, teaching-intensive, and college-technical institutions differs by ethno-linguistic background and high school grades. Estimates from multi-level logistic regression models demonstrate that Korean, Tagalog, and Vietnamese speakers have lower probabilities of degree completion than English-speaking students. The type of institution a student initially enters is, however, an important correlate of degree completion for all ethno-linguistic groups. Students with lower high school grades who initially enter a research-intensive institution are more likely to graduate compared with higher-achieving students who enter a teaching-intensive or college-technical institution. To improve completion by institutional type and among ethno-linguistic groups, our study highlights the need for research on why degree completion is lower at certain institutions for all ethno-linguistic groups and consistently lower among Korean, Tagalog, and Vietnamese speakers regardless of their level of academic achievement in high school or the type of post-secondary institution they initially entered.
\end{abstract}

Keywords: post-secondary completion, British Columbia, ethno-linguistic background, high-school grade point average

\section{Résumé}

Nous examinons le taux d'obtention du diplôme de baccalauréat dans le système d'enseignement supérieur de la Colombie-Britannique, notable pour la variété des voies qu'il offre vers la diplomation et sa population estudiantine ethniquement diversifiée. En utilisant un ensemble de données administratives longitudinales, nous regardons comment la probabilité d'acquérir un diplôme dans les universités de recherche, les universités d'enseignement et les universités techniques varie en fonction de l'origine ethnolinguistique de l'étudiant et de ses résultats au secondaire. Les estimations basées sur des modèles de régression logistique multiniveau montrent que dans l'ensemble, les étudiants de langue maternelle coréenne, tagalog ou vietnamienne sont moins susceptibles d'acquérir un diplôme que les étudiants de langue maternelle anglaise. De plus, le type d'établissement où un étudiant commence ses études supérieures est lié au taux d'acquisition ultérieur du diplôme pour tous les groupes ethnolinguistiques. Les étudiants qui intègrent une université de recherche, même avec des résultats moins bons au secondaire, sont plus susceptibles d'obtenir leur diplôme que les étudiants ayant obtenu de meilleurs résultats au secondaire, mais qui intègrent une université d'enseignement ou une université technique. Afin d'améliorer le taux de succès dans chaque catégorie d'établissement et groupe ethnolinguistique, notre étude souligne la nécessité de mener des recherches sur les raisons d'un taux de succès inférieur dans certains types d'établissements pour tous les groupes ethnolinguistiques, et particulièrement pour les étudiants de langue maternelle coréenne, tagalog et vietnamienne, indifféremment de leur niveau scolaire à la fin du secondaire ou du type d'établissement d'enseignement supérieur qu'ils ont intégré à la fin de leurs études secondaires.

Mots-clés : diplôme supérieur, Columbie Britannique, origines ethno-linguistiques, résultats de fin d'études secondaires

\section{Introduction}

Among individuals who enroll in a bachelor's degree (BA/BSc) program, fewer than two-thirds complete their studies within 6 years (Childs, Finnie, \& Martinello, 2017; Heslop, 2015). This disjuncture in admission and graduation rates raises policy concerns around government 
expenditures, institutional effectiveness, and high school graduates' academic preparedness for post-secondary education (PSE) (Ministry of Training, Colleges and Universities, 2015). At the individual level, failure to successfully complete a degree disappoints aspirations, disrupts career plans, and often incurs financial penalties (Finnie, Childs, \& Qiu, 2012; Ma \& Frempong, 2013).

Higher education policy researchers have responded by shifting attention from issues of equity in admissions to an exploration of the determinants of retention, program persistence, and degree completion (Finnie, Mueller, Sweetman, \& Usher, 2008; Kelly \& Schneider, 2012). In this paper, we contribute to the literature by using the British Columbia (BC) PSE system as a case study of the antecedents and correlates of degree completion for a youth cohort born in 1990-with a particular focus on how BA/BSc completion differs by students' ethno-linguistic status, high-school grade point average, and the type of institution they initially enter. British Columbia's PSE system is characterized by multiple pathways to a degree, including traditional four-year undergraduate and two-year degree transfer programs. In high choice, merit-based PSE systems, both admission and degree completion requirements are expected to balance equality of opportunity with academic excellence (Fisher et al., 2014). Our examination of degree completion determinants thus considers students' personal characteristics and social contexts in relation to their school and university experiences. We extend existing analyses by accounting for recent organizational reforms to the university system as well as changes in the student population, primarily its ethnic composition.

\section{Literature Review}

\section{Determinants of BA/BSc Degree Comple- tion}

Studies of degree completion in Canada typically focus on the pathways followed by students as they navigate the PSE system (Conrad \& Morris, 2010; Parkin \& Baldwin, 2009) and determinants of degree completion (Finnie et al., 2008; Mueller, 2008). With the publication of the Youth in Transition Survey (YITS), nationally-representative longitudinal data became available for analyses of students' transition from high school to PSE, their university experience, and eventual degree completion (Barr-Telford, Cartwright, Prasil \& Shimmons, 2003; Finnie \& Qiu, 2008; Motte, Qiu \& Bussiere, 2008). Research on the determinants of completion using YITS data have examined social structures, student characteristics, and institutional features (Lambert, Zeman, \& Allen, 2004). These studies reported a positive association between high school grades and degree completion (Christofides, Hoy, Milla \& Stengos, 2015), as well as positive relationships between graduation and family socio-economic status (SES), being female, and attending an urban school (Childs, Finnie, \& Martinello, 2017). Due to sampling limitations in YITS, however, ethnic or racial differences were not examined or were aggregated and treated as a single 'visible minority' category (e.g., Thiessen, 2009).

Other studies have employed alternative data sources to examine the relationship between high-school grade point average (HSGPA) and PSE graduation. In BC, Andres (2015) demonstrated that both SES and HSGPA are associated with participation and completion. Although this research summary observed higher graduation rates for women, their attainment was often gendered by field of study (Andres \& Adamuti-Trache, 2007). Dooley, Payne, and Robb's (2012) study of BA/BSc completion at four Ontario universities also utilized social background factors and HSGPA information obtained from administrative records. It found that, while higher SES and being female were positively related to completion, neither measure had a significant effect on completion once HSGPA was included in the analysis.

Few Canadian studies have considered how BA/BSc completion differs by race, ethnicity, and immigration status. An exception is Abada, Hou and Ram (2009) who employed a cross-sectional national survey to study ethnic differences in educational attainment among second-generation immigrant youth. They reported that Asian-origin groups had particularly high levels of BA/BSc attainment, although marked variations in degree aspirations and attainment were observed. While expanding the scope of analyses to include a more detailed examination of ethnic differences in educational attainment, the study's data source did not contain information on HSGPA.

Research on degree completion also highlights the importance of the PSE experience itself. Institutions differ in faculty expertise and in the resources available to support students across a range of academic, financial, and social-emotional needs (Barr-Telford et al., 2003). Among the most widely utilized 'quality index' scales is the 
annual Canadian university ranking report published by Maclean's Magazine. Approaches to the analyses of institutional quality-including ranking-have been examined by Finnie and Usher (2005) who indicated the conceptual and measurement difficulties involved. Related studies are limited in number and scope, dealing largely with the consequences of rising tuition and the prospect of debt as constraints on completion (Finnie \& Qui, 2008).

\section{Institutional Differentiation and Degree Completion}

As a result of system expansion, Canadian universities have become differentiated in size, resources, and curricular scope such that a distinct 'status hierarchy' has emerged (Davies, Maldonado \& Zarifa, 2014; Davies \& Zarifa, 2012). In the BC system, expanded BA/BSC programming has resulted in distinctions among research-intensive universities (RIUs), teaching-intensive universities (TIUs), and college-technical institutes (CTs). With legislative change in 2002, many former community colleges were reconfigured to offer four-year programming with degree granting status. In addition to these new degree pathways, the 'college-to-university' transfer system remains in place. This pathway typically involves enrolling for one to two years at a $\mathrm{CT}$, then transferring to either an RIU or TIU to complete the BA/BSc degree (Fisher et al., 2014).

Although BA/BSc programming across institutional types may be comparable, RIUs are more academically selective in admitting students, as seen in their higher entering HSGPA requirements (Arida, 2013). This has encouraged intense competition for admission to many RIU programs, resulting in claims of unequal access across SES, gender, and race-ethnicity dimensions (Cui \& Kelly, 2013; Sweet, Robson \& Adamuti-Trache, 2017). There nevertheless may be benefits to enrolling in an RIU that justify this level of competition. For example, data on CT transfer students in BC indicate much lower BA/BSc completion rates, although many complete two-year associate's degree programs (Cowin, 2013). These results are consistent with US-based studies with similar community college structures and transfer pathways (Goodman, Hurwitz, \& Smith, 2015).

Selective admissions attempts to align a student's HSGPA with an institution's position in the PSE status hierarchy. There is evidence such academic matching improves degree completion (Kelly \& Schneider, 2012). However, the extensive literature on student-university match based on HSGPA also suggests the need for a broader assessment of the 'fit' between student characteristics and the general features of the institution attended (Kelly, Howell, \& Sattin-Bajaj, 2016). Students choose institutions and programs in relation to financial, geographic, and cultural considerations and, where a better fit is achieved in these respects, completion rates improve (Howell, Pendar, \& Kumar, 2016). Other fit patterns are found at the curricular level where students' choose majors or express preferences for the various course and program options in the BA/BSC program (Hallsten \& Thaning, 2018).

\section{Student Diversity}

Historically, the profile of the traditional PSE student in BC (and Canada) has been English-speaking, white, middle-class, and male, although in the past 30 years the gender balance has shifted in favour of female attendance and the socio-economic base has broadened somewhat (Card, Payne, \& Sechel, 2011; Lehmann, 2014). The BC student population has also become more culturally diverse, reflecting ongoing changes in the ethnic composition of the province. Currently, Asian-origin communities account for over $50 \%$ of the population in Metro Vancouver and $30 \%$ in the rest of the province, both markedly higher than the national average of $22 \%$ (Statistics Canada, 2015).

For ethnic-immigrant groups, the PSE system offers a means of resolving social integration and mobility challenges (Costigan, Hua, \& Su, 2010; Taylor \& Krahn, 2013). Studies of the relationship between ethnicity, PSE participation, and educational attainment have employed an 'ethnic capital' framework that positions families within a network of community resources designed to support children's PSE aspirations as well as the dispositions underlying school engagement and achievement (Abada et al., 2009; Lee \& Zhou, 2015). More recent theoretical formulations extend the notion of ethnic capital to better suit emerging 'majority-minority' regions-typically urban environments comprising highly diverse ethnic-immigrant communities and their constituent institutions. In these settings, differences in the educational values and practices of established and immigrant-ethnic student groups (and their parents) are frequently encountered and require resolution. Jimenez and Horowitz (2013), for exam- 
ple, describe the formation of academic norms in selected California schools by ethnic-majority Asian students that differed from and eventually displaced those of the established student body. Crul, Keskiner and Lelie (2017) similarly describe successful educational trajectories of immigrant-ethnic youth that reconfigure ethno-racial hierarchies in 'super-diverse' European contexts. Several studies have outlined the shift to ethnic majority-minority status in major North American cities (Frey, 2014; Hiebert, 2015). The comparative educational success of Asian youth in these settings has been attributed in both academic and popular publications to expressions of ethnic capital-specifically, to differences in the educational values and actions of parents (Chua, 2011; Ng \& Wang, 2019; Zhou \& Kim, 2006). Other researchers acknowledge these cultural distinctions but point to a growing convergence in parents' aspirations for and commitment to their children's education, irrespective of ethnicity (Bornstein, 2012; Jimenez, 2017; Warikoo, 2018).

\section{Purpose}

In this paper, we frame our analysis of ethnic students' PSE transitions in relation to two constructs: ethnic capital and student-institution matching. The former attempts to explain student achievement as a consequence of parentally and culturally driven preparation during the $\mathrm{K}-12$ period, while the latter sets out parameters for understanding the relationship between HSGPA and both selective admissions and degree completion. The principle of merit applied at admissions is based primarily on HSGPA, although other factors like SES, gender, and ethnicity are recognized as influencing students' academic achievement and consequently admission results. The logic of relying on HSGPA as the criterion of merit at admissions further assumes that PSE success builds on an academic foundation developed during the K-12 school period. Students' PSE experiences are nevertheless strongly influenced by the resources and opportunities available at institutions comprising the various pathways. Our analysis examines both the institutional influence of pathway choice and the role played by HSGPA in determining the linked transitions of university admissions and degree completion in a culturally diverse PSE system.

\section{Analytical Approach}

\section{Data and Sample}

Using BC Ministry of Education and Student Transitions Project administration files, we constructed a longitudinal dataset that allows examination of a student's progress through the K-12 and PSE systems. This student-level dataset captures students born in 1990 and for whom the earliest education records begin in 1993 and extend to 2016. Together the administrative records include information on high school (e.g., HSGPA and school-level median family income), student characteristics (e.g., ethno-linguistic status), and PSE (e.g., entry dates, institution, field of study).

Analysis is limited to a sub-set of students who graduated from a BC high school (typically in the 20072008 school year), entered a BA/BSC degree or university-transfer program, and for whom PSE completion information was available. Because previous research indicates the typical 'on-time' completion timeline is five to six years for "direct from high school students" (Heslop, 2015, p.14), we limit the sample to students who entered a BA/BSC program within two years of completing high school and thus had a chance to graduate 'on time' within the period covered by the data set ${ }^{1}$. The sample used for analysis also includes only students who graduated from a BC school district (both public and independent schools) and excludes students enrolled in offshore schools.

\section{Variables}

The dependent variable captures BA/BSc degree completion by 2016 (e.g., on-time completion) and is operationalized through a binary dummy indicator ( $0=$ non-completion, 1=completion). As listed in Appendix 1, among the 16,795 students in our sample who are identified as entering a BA/BSc or university transfer program, $60 \%$ completed a BA/BSc within the time period under study.

The main independent variables of interest are: ethno-linguistic status; the type of PSE institution a student first entered after high school graduation; HSGPA; and an interaction term between institutional type at entry and HSGPA. Seven categories represent ethno-linguistic status-English, European, South Asian, Chinese, Korean, Tagalog/Vietnamese, and Other-and were recorded in the $\mathrm{K}-12$ administrative files as the main language spoken 
at home. Three categories represent institutional type at PSE entry (RIUs, TIUs, and CTs); a categorization based on established institutional groupings in the BC PSE system (Heslop, 2015)2. Appendix 2 provides an overview of how each $\mathrm{BC}$ institution is categorized and indicates those removed from the analysis due to their small cluster sizes. HSGPA is based on a standard grade point average metric ranging from 1 to 4 . This variable is also redefined as a categorical variable to represent four HSGPA groups: 24th percentile and under, 25th-49th percentile, 50th-74th percentile, and 75th percentile and above.

The analysis also includes several control variables that prior research suggests are associated with the outcome variable and which, additionally, may influence relationships between completion and the independent variables of primary interest in this study ${ }^{3}$. Indicators represent gender (male $=0$, female $=1$ ) and Indigenous status ( $0=$ no, 1=yes). Variables also capture participation in an English as a second/foreign language (ESL) program at any point during $\mathrm{K}-12$ ( $0=\mathrm{no}, 1=\mathrm{yes})$, the school grade level at which a student first appeared in the administrative data (primary, elementary, junior secondary, and senior secondary entry), and whether the last high school attended was located in Metro Vancouver ( $0=$ no, 1=yes). A continuous measure of median family income represents
SES at the school level ${ }^{4}$. PSE factors that may influence degree completion include field of study (FOS) recorded at entry (undeclared, STEM applied, STEM academic, non-STEM applied, and non-STEM academic) ${ }^{5}$ and the gap between high-school graduation and PSE entry (immediate, one year, or two years).

\section{Analysis}

Given the selective nature of admissions in the hierarchical BC system, a student's HSGPA largely determines their entry to an RIU, TIU, or CT. As Figure 1 illustrates, the distributions of HSGPA among incoming TIU and CT students are similar, while the HSGPAs of incoming RIU students are higher on average. As expected, students with higher HSGPA are more likely to initially enter an RIU. As the descriptive statistics in Appendix 1 also show, RIU students have higher degree completion rates on average (i.e., $75 \%$ compared to $43 \%$ among TIU student and $35 \%$ among CT students). From descriptive statistics alone, however, it is unclear whether the higher observed RIU completion rates are due to institutional effects or the academic preparedness of the incoming student population.
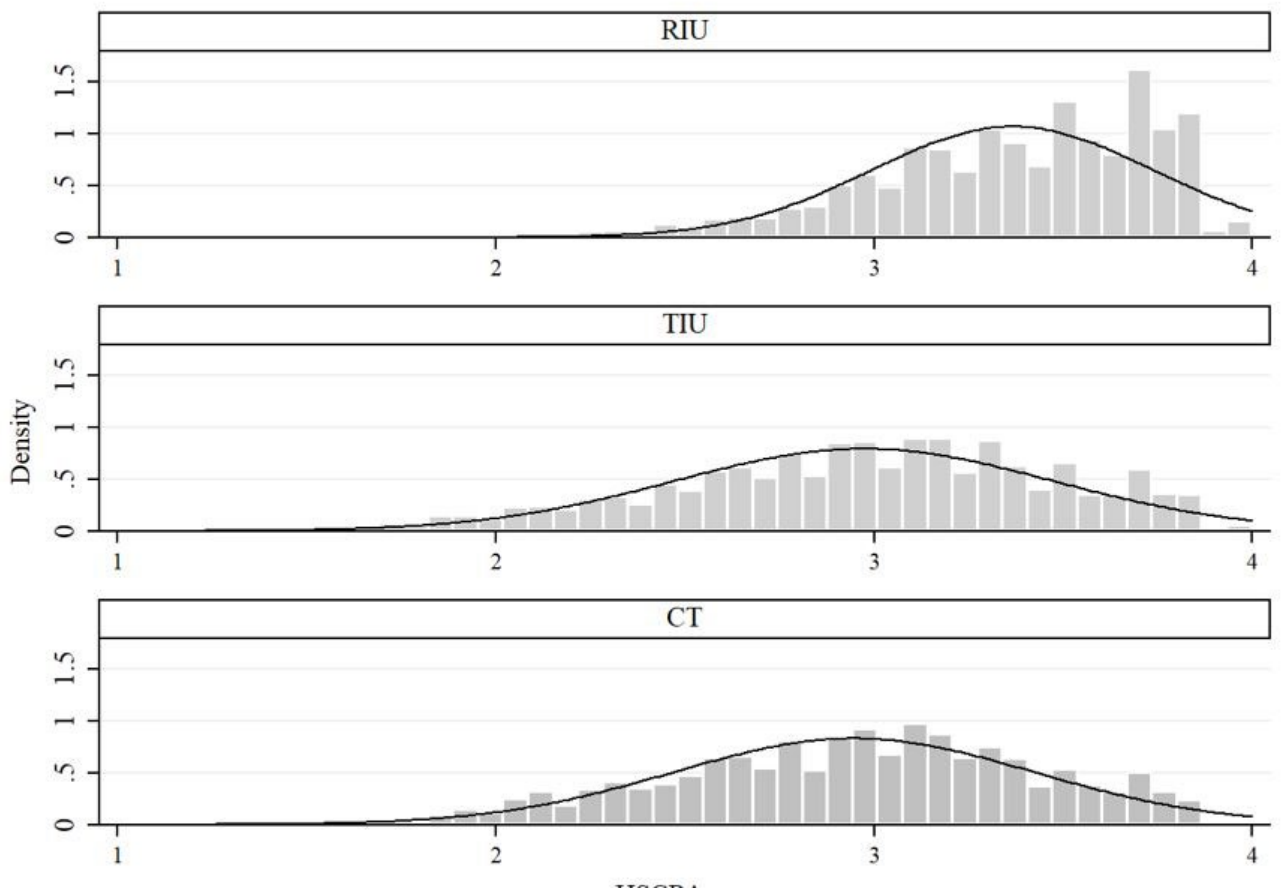

HSGPA

Figure 1. Frequency distribution of HSGPA across institutional type at entry 
In order to address this confounding effect, we generate inverse probability (IP) weights (Hernán \& Robins, 2018). The weights are created by calculating the inverse of a student's probability of attending an RIU based on their HSGPA (i.e., a student who is more likely to attend an RIU given their HSGPA is less influential on the overall model). To determine how IP weights influence the overall results, all analyses are run both with and without weighting. As well as accounting for the confounding effect between HSGPA and institutional type at entry, the IP weights also provide insight into how pathway choice may result in differential outcomes for ethno-linguistic groups.

The modeling approach is based on multilevel logistic regression that accounts for PSE institutional clustering. It examines how ethno-linguistic category, institutional type at entry, and HSGPA —as well as the interaction between institutional type at entry and HSGPA-are associated with BA/BSC completion. Because institutional clustering has an important impact on the results, a baseline logistic regression (i.e., Model 0 ) shows how completion for each ethno-linguistic group differs from English-speaking students without accounting for the institutions each student was most likely to initially attend. Model 1 then provides the multilevel specification while Model 2 adds institutional type at entry, HSGPA, and an interaction term between these two indicators. Model 3 adds all control variables.
In this analysis, the regression coefficients are transformed into average marginal effects (AME). As described further in the results section, each categorical variable is interpreted as the predicted probability (i.e., percentage point difference) of completion compared to the reference group. To further examine how completion differs in relation to the main variables of interest, we construct graphs that show the AME of HSGPA, institutional type, and ethno-linguistic group on BA/BSc completion. Unlike the regression results, which compare the predicted probability of completion to a reference group (e.g., completion at CT vs. RIU), these Model 3 estimates generate AME that represent "the partial effect averaged across the specified population" (Wooldridge, 2016, p. 844). These estimates are produced without IP weights.

\section{Results}

Figure 2 provides a descriptive overview of ethno-linguistic differences in the institution type at initial enrollment. Most Chinese and Korean speakers enrolled in an RIU and were under-represented within TIU or CT pathways. Conversely, a larger proportion of South Asian language students initially enrolled in a TIU but were under-represented in RIUs. Finally, apart from English language speakers, far fewer students enrolled in the CT pathway.

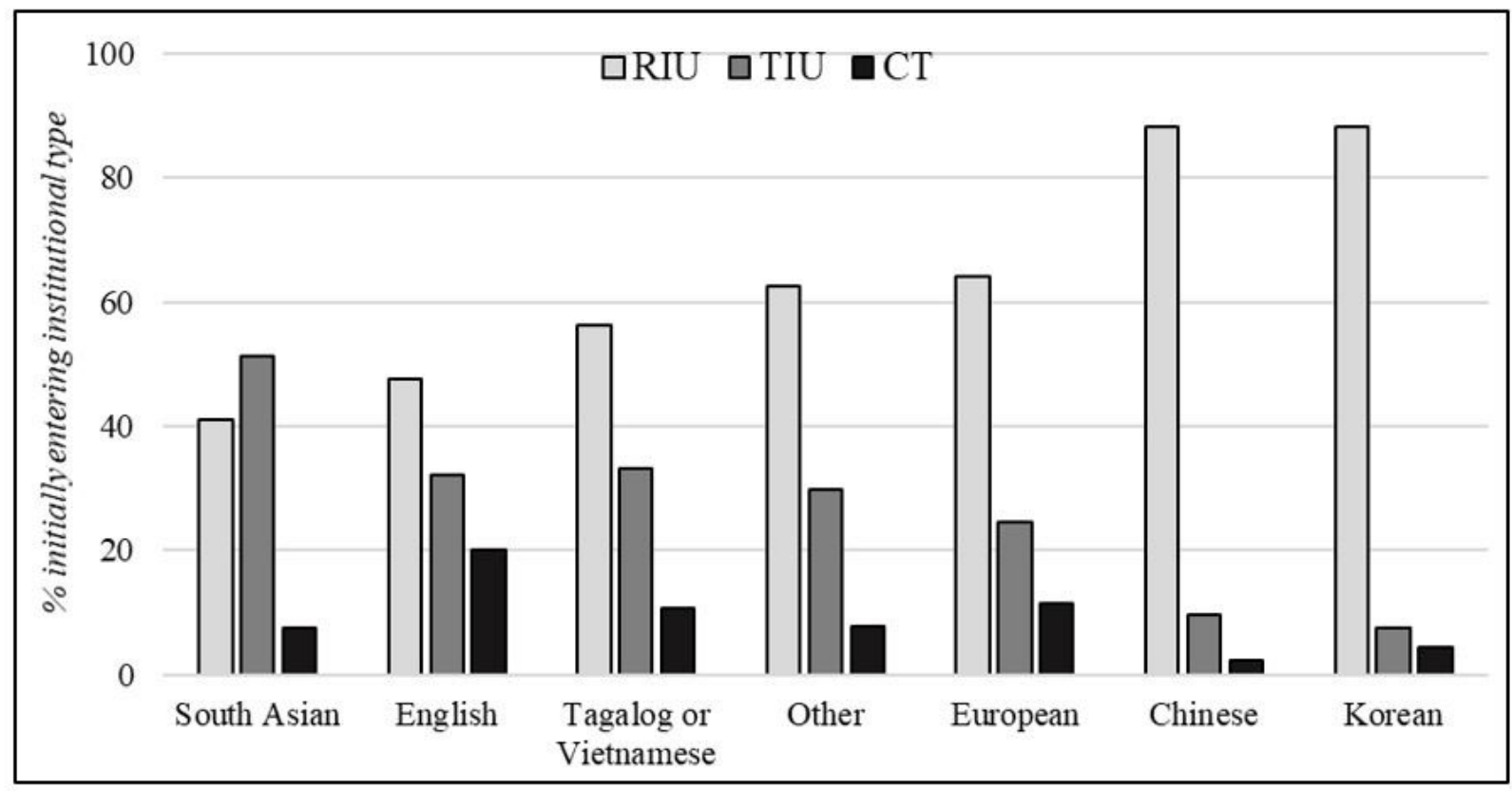

Figure 2. Institutional type at entry by ethno-linguistic group 


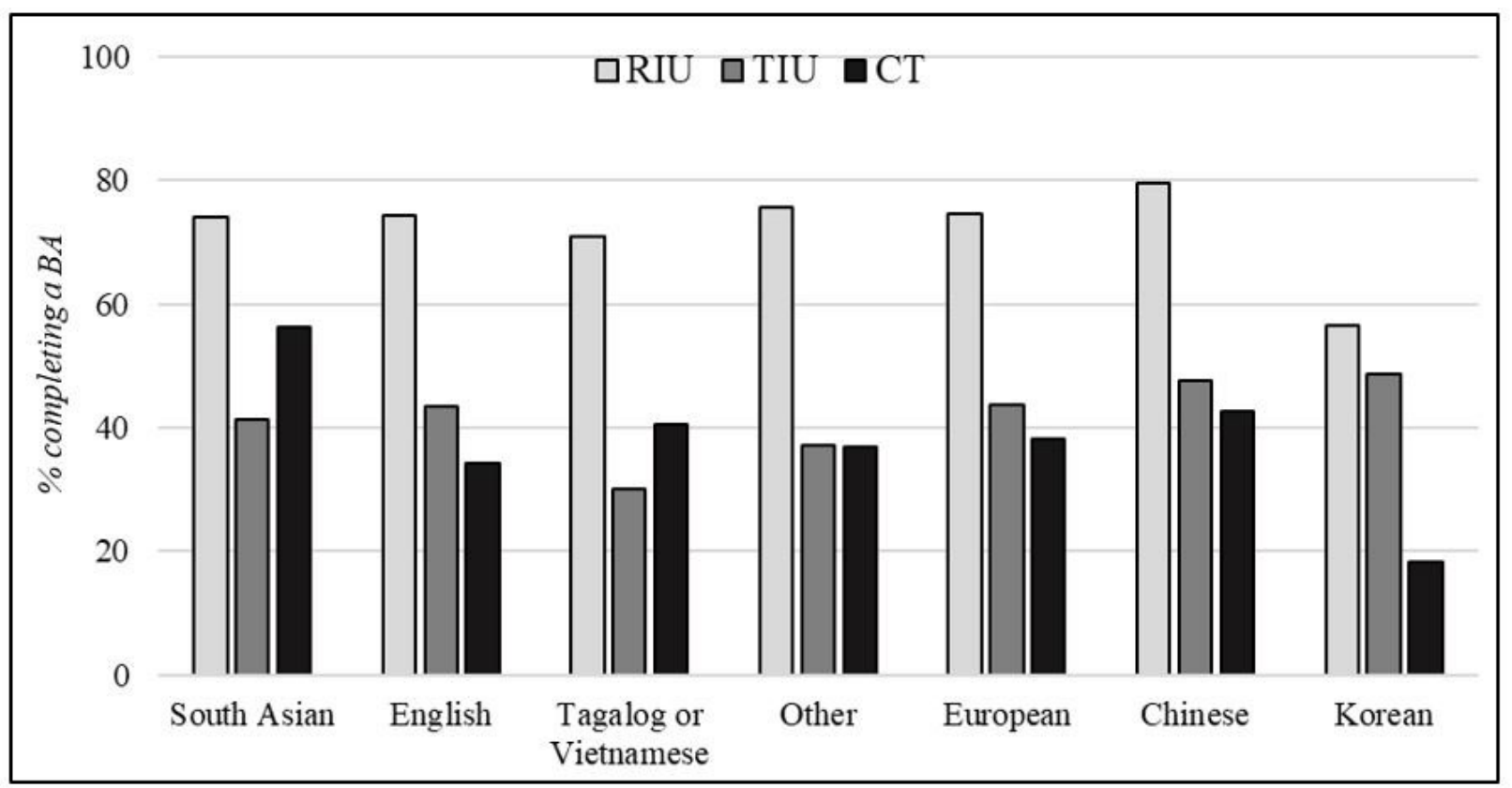

Figure 3. Degree completion rate by ethno-linguistic group and institutional type at entry

Figure 3 provides descriptive statistics on ethno-linguistic differences in BA/BSc completion by institutional type at entry. In comparing students' degree completion rates across RIU, TIU and CT pathways, students from all ethno-linguistic groups who initially enter an RIU are more likely to graduate. Among RIU students, Korean speakers have lower attainment while Chinese speakers have slightly higher attainment in comparison with other ethno-linguistic groups. Tagalog/Vietnamese speakers have lower attainment at TIUs compared to other TIU students. Chinese and Tagalog/Vietnamese speakers have higher attainment at CTs compared to other CT students.

Comparing degree completion in relation to institutional type at entry for the various ethno-linguistic groups suggests the RIU pathway results in high completion rates for only some groups. Chinese speakers have high completion rates at RIUs and are equally successful when entering TIU and CT programs. Despite similarly high levels of initial enrolment in RIUs, Korean speakers' degree completion rates are relatively low. This contrasts with their performance at TIUs, although relatively few Korean speaking students choose this pathway. Students who speak a South Asian language who initially enroll in TIUs have relatively low degree completion rates. While the CT pathway enrols relatively fewer students from the various ethno-linguistic groups (apart from English speakers), Tagalog/Vietnamese speakers who enrol in these institutions do relatively well.

Table 1 estimates the predicted probability (i.e., AME) of BA/BSc completion by ethno-linguistic group, HSGPA, and institutional type at entry - with and without IP weight and control variables. Model 0 first estimates a baseline logistic regression that does not account for the effect of institutional clustering. The results are effectively the same as those presented in Appendix 1. That is, compared to English speaking students, European language speakers are 6.5 percentage points more likely to graduate, Chinese speakers are 19 percentage points more likely to graduate, and the Other group of language speakers are 4.9 percentage points more likely to graduate.

Table 1. Regression estimates of BA/BSc completion, AME

\begin{tabular}{|c|c|c|c|c|c|c|}
\hline Baseline & \multicolumn{3}{|c|}{ Multilevel Logit } & \multicolumn{3}{|c|}{ Multilevel Logit } \\
\hline Logit & \multicolumn{3}{|c|}{ Without IP weights } & \multicolumn{3}{|c|}{ With IP Weights } \\
\hline Model 0 & Model 1 & Model 2 & Model 3 & Model 1 & Model 2 & Model 3 \\
\hline
\end{tabular}

Ethnolinguistic groups (ref: English) 


\begin{tabular}{|c|c|c|c|c|c|c|c|}
\hline & \multirow{2}{*}{$\begin{array}{c}\text { Baseline } \\
\text { Logit }\end{array}$} & \multicolumn{3}{|c|}{ Multilevel Logit } & \multicolumn{3}{|c|}{ Multilevel Logit } \\
\hline & & \multicolumn{3}{|c|}{ Without IP weights } & \multicolumn{3}{|c|}{ With IP Weights } \\
\hline & Model 0 & Model 1 & Model 2 & Model 3 & Model 1 & Model 2 & Model 3 \\
\hline \multirow[t]{2}{*}{ European } & $0.065^{* * *}$ & -0.012 & 0.0049 & -0.0029 & -0.026 & -0.0100 & -0.017 \\
\hline & $(0.017)$ & $(0.012)$ & $(0.013)$ & $(0.016)$ & $(0.015)$ & $(0.016)$ & $(0.017)$ \\
\hline \multirow[t]{2}{*}{ South Asian } & -0.0042 & 0.019 & $0.041^{*}$ & 0.023 & 0.0072 & 0.034 & 0.017 \\
\hline & $(0.017)$ & $(0.015)$ & $(0.019)$ & $(0.027)$ & $(0.015)$ & $(0.023)$ & $(0.030)$ \\
\hline \multirow[t]{2}{*}{ Chinese } & $0.19^{* * *}$ & 0.016 & $0.043^{*}$ & 0.027 & -0.0094 & 0.028 & 0.015 \\
\hline & $(0.009)$ & $(0.016)$ & $(0.019)$ & $(0.015)$ & $(0.018)$ & $(0.017)$ & $(0.012)$ \\
\hline \multirow[t]{2}{*}{ Korean } & -0.020 & $-0.20^{* * *}$ & $-0.18^{* * *}$ & $-0.15^{* * *}$ & $-0.25^{* * *}$ & $-0.21^{* * *}$ & $-0.19^{* * *}$ \\
\hline & $(0.022)$ & $(0.031)$ & $(0.024)$ & $(0.031)$ & $(0.044)$ & $(0.036)$ & $(0.045)$ \\
\hline \multirow[t]{2}{*}{ Tagalog/Vietnamese } & -0.022 & $-.073^{* * *}$ & $0.068^{* * *}$ & $0.083^{* * *}$ & $-0.095^{* *}$ & $-0.088^{* *}$ & $-0.100^{* *}$ \\
\hline & $(0.027)$ & $(0.015)$ & $(0.021)$ & $(0.015)$ & $(0.029)$ & $(0.031)$ & $(0.032)$ \\
\hline \multirow[t]{2}{*}{ Other } & $0.049^{* *}$ & -0.022 & 0.016 & 0.0046 & $-0.037^{*}$ & 0.011 & 0.0030 \\
\hline & $(0.019)$ & $(0.013)$ & $(0.011)$ & $(0.012)$ & $(0.018)$ & $(0.018)$ & $(0.012)$ \\
\hline \multicolumn{8}{|c|}{ Institutional type at entry (ref: RIU) } \\
\hline \multirow[t]{2}{*}{ TIU } & & & $-0.17^{*}$ & $-0.18^{*}$ & & -0.12 & -0.12 \\
\hline & & & $(0.081)$ & $(0.079)$ & & $(0.074)$ & $(0.073)$ \\
\hline \multirow[t]{2}{*}{ CT } & & & $-0.27^{* * *}$ & $-0.27^{* * *}$ & & $-0.20^{*}$ & $-0.19^{* *}$ \\
\hline & & & $(0.070)$ & $(0.061)$ & & $(0.078)$ & $(0.070)$ \\
\hline \multicolumn{8}{|c|}{ High-school GPA (ref: 1-24 per.) } \\
\hline \multirow[t]{2}{*}{ 25-49 percentile } & & & $0.13^{* * *}$ & $0.11^{* * *}$ & & $0.15^{* * *}$ & $0.14^{* * *}$ \\
\hline & & & $(0.011)$ & $(0.015)$ & & $(0.013)$ & $(0.018)$ \\
\hline \multirow[t]{2}{*}{ 50-74 percentile } & & & $0.23^{* * *}$ & $0.21^{* * *}$ & & $0.26^{* * *}$ & $0.24^{* * *}$ \\
\hline & & & $(0.022)$ & $(0.027)$ & & $(0.023)$ & $(0.029)$ \\
\hline \multirow[t]{2}{*}{ 75-99 percentile } & & & $0.28^{* * *}$ & $0.26^{* * *}$ & & $0.31^{* * *}$ & $0.29^{* * *}$ \\
\hline & & & $(0.029)$ & $(0.034)$ & & $(0.027)$ & $(0.035)$ \\
\hline \multicolumn{8}{|c|}{ Interaction terms (Ref: RIU) } \\
\hline \multirow[t]{2}{*}{ TIU*25-50 } & & & $0.037^{* * *}$ & $0.031^{*}$ & & 0.0027 & 0.00014 \\
\hline & & & $(0.010)$ & $(0.015)$ & & $(0.012)$ & $(0.017)$ \\
\hline \multirow[t]{2}{*}{ TIU*50-75 } & & & $0.084^{* * *}$ & $0.085^{* * *}$ & & $0.050^{*}$ & 0.052 \\
\hline & & & $(0.022)$ & $(0.025)$ & & $(0.024)$ & $(0.028)$ \\
\hline \multirow[t]{2}{*}{ TIU*75-100 } & & & $0.13^{* * *}$ & $0.13^{* * *}$ & & $0.10^{* * *}$ & $0.10^{* *}$ \\
\hline & & & $(0.029)$ & $(0.034)$ & & $(0.029)$ & $(0.036)$ \\
\hline \multirow[t]{2}{*}{$\mathrm{CT}^{*} 25-50$} & & & $0.070^{* *}$ & $0.067^{* *}$ & & 0.038 & 0.039 \\
\hline & & & $(0.021)$ & $(0.023)$ & & $(0.023)$ & $(0.026)$ \\
\hline CT*50-75 & & & 0.033 & 0.037 & & -0.0008 & 0.0061 \\
\hline
\end{tabular}




\begin{tabular}{|c|c|c|c|c|c|c|c|}
\hline \multirow{3}{*}{\multicolumn{2}{|c|}{$\begin{array}{r}\text { Baseline } \\
\text { Logit } \\
\text { Model } 0\end{array}$}} & \multirow{2}{*}{\multicolumn{3}{|c|}{$\begin{array}{c}\text { Multilevel Logit } \\
\text { Without IP weights }\end{array}$}} & \multirow{2}{*}{\multicolumn{3}{|c|}{$\begin{array}{l}\text { Multilevel Logit } \\
\text { With IP Weights }\end{array}$}} \\
\hline & & & & & & & \\
\hline & & Model 1 & Model 2 & Model 3 & Model 1 & Model 2 & Model 3 \\
\hline & & & $(0.038)$ & $(0.041)$ & & $(0.040)$ & $(0.044)$ \\
\hline \multirow{2}{*}{$\mathrm{CT}^{*} 75-100$} & & & $0.071^{*}$ & $0.075^{*}$ & & 0.043 & 0.047 \\
\hline & & & $(0.031)$ & $(0.036)$ & & $(0.032)$ & $(0.037)$ \\
\hline Controls & & & & Included & & & Included \\
\hline Observations & & & & 16,795 & & & \\
\hline
\end{tabular}

Standard errors in parentheses; ${ }^{*} p<0.05,{ }^{* *} p<0.01,{ }^{* * *} p<0.001$; The baseline logit model presents the results without accounting for the clustering effect of institution of entry $(n=22)$. The multilevel logit models demonstrate how the results change with the inclusion of the main independent (Model 2) and control variables (Model 3). Model three controls for: gender; Indigenous ancestry; prior K-12 ESL training; if a student's high school was located in Metro Vancouver; timing of entry to the BC K-12 system; field of study at PSE entry, and timing of PSE entry.

Because institutional type at entry varies by ethno-linguistic status, the multilevel specifications that account for this differ from the baseline logistic regression model. Models 1 to 3 illustrate that differences in the predicted probabilities of degree completion between English and Chinese, European, and Other language students are greatly reduced once a model accounts for the institutional clustering effect. However, new ethno-linguistic differences emerge in relation to institutional type at entry. These are seen in estimates that show degree completion rates for some groups are lower than would be expected given their admission to PSE institutions with high graduation rates overall. More specifically, compared to English speakers, Model 1 without IP weights estimates that Korean language speaker have graduation rates that are 20 percentage points lower and Tagalog/Vietnamese speakers have graduation rates that are 7.3 percentage points lower. Once IP weights are included in Model 1, Korean language students have estimated graduation rates that are 25 percentage points lower and Tagalog/ Vietnamese speakers have rates that are 9.5 percentage points lower compared to English speaking students. The inclusion of control variables also alters the results, reducing the AME for Korean language speakers and increasing the AME for Tagalog/Vietnamese speakers.

Model 2 demonstrates that, as expected, the likelihood of BA/BSc completion is associated with institutional type at entry. Model 2 without IP weights estimates that students who initially enter TIUs are 17 percentage points less likely to graduate compared to students who enter RIUs, while students who first enroll in CTs are an estimated 27 percentage points less likely to graduate. However, the inclusion of IP weights reduces these coefficients and eliminates the statistically significant difference between TIUs and RIUs.

Also as expected, Model 2 demonstrates that HSGPA is associated with degree completion. In Model 2 without IP weights, students with average HSGPA in the 25th to 49th percentile have a predicted probability of completion that is 13 percentage points higher compared to students at the 24th HSGPA percentile and under. This difference widens as students with a HSGPA in the 50th to 74th percentile have a predicted probability of completion that is 23 points higher and students with a HSGPA at the 75th percentile or above have a predicted probability of completion that is 28 points higher. The inclusion of control variables in Model 3 reduces the AME by a few percentage points, while the inclusion of IP weights increases the AME by a few percentage points.

Model 2 also includes categorical-by-categorical interactions between institutional type at entry and HSGPA to estimate whether the difference in completion rates by institutional type (e.g., RIU vs. TIU and RIU vs. CT) differs by HSGPA quartile (e.g., compared to the 1st-24th percentile). In Model 2 without IP weights, the RIU vs. TIU completion rate difference narrows at higher HSGPA quartiles-that is, it narrows by 13 percentage points compared to the completion rate difference for students in the 1st-24th percentile group. Among students with lower HSGPAs, completion rates are higher for those who initially attend RIUs compared to TIUs. Among students with higher HSGPAs, completion rates are more similar re- 
gardless of whether they attend an RIU or a TIU although a difference in favor of RIUs still exists. By contrast, the CT vs. RIU completion rate difference does not narrow for high HSGPA students to the same degree. That is, students who enter CT have lower degree completion rates than those who enter RIUs and this difference narrows only slightly (i.e., 7 percentage points in Model 2 without IP weight) for students in the highest HSGPA quartile compared to the lowest quartile. Finally, the inclusion of control variables in Model 3 does not produce dramatic changes although IP weights in Model 2 and 3 reduce the size and significance of the interaction terms, especially for CTs.

In summary, the IP weights-which account for the probability that high achieving high school students will initially enter an RIU_provide additional understanding of ethno-linguistic differences in BA/BSC completion. In comparing the results of Model 2 with and without IP weights, we see that weighting reduces the size and significance of the AME for Chinese and South Asian speakers. This result suggests that high achieving Chinese and South Asian language groups are more likely to initially go to RIUs and also more likely to complete a degree. However, the IP weights have the opposite result when comparing completion rates between Korean/Tagalog/Vietnamese and English language students. Here, the inclusion of IP weights increases the AME for these groups. This result suggests that high achieving Korean and Tagalog/Vietnamese speakers are more likely to initially enroll in RIUs but are less likely to complete a degree. To examine these patterns in greater depth, we next compare ethno-linguistic groups at the same achievement level in terms of how their probability of completion differs by institutional type at entry.

Figure 4 presents the AME of BA/BSc completion for the three institutional types or pathways, by ethno-linguistic group, and with each group's average HSGPA values indicated as percentile ranges. These results are derived from Model 3 without IP weights. Across institutional types, the probability of degree completion is positively associated with HSGPA. Completion is lowest for all ethno-linguistic groups who enter at the 24th percentile and lower; and highest for those groups who enter institutions in the 75th percentile or above. However, completion is more likely if initial enrolment is in an RIU, irrespective of ethno-linguistic group or HSGPA. Lower HSGPA students who initially went to RIUs have higher completion probabilities than higher HSGPA students who initially enrolled in TIUs or CTs. This contrast is more pronounced in the case of CT enrolments. For example, students with an HSGPA at or above the 75th percentile who initially enter a CT have an estimated AME that is lower than that of RIU entrants with an HSGPA between the 50th and 74th percentiles.

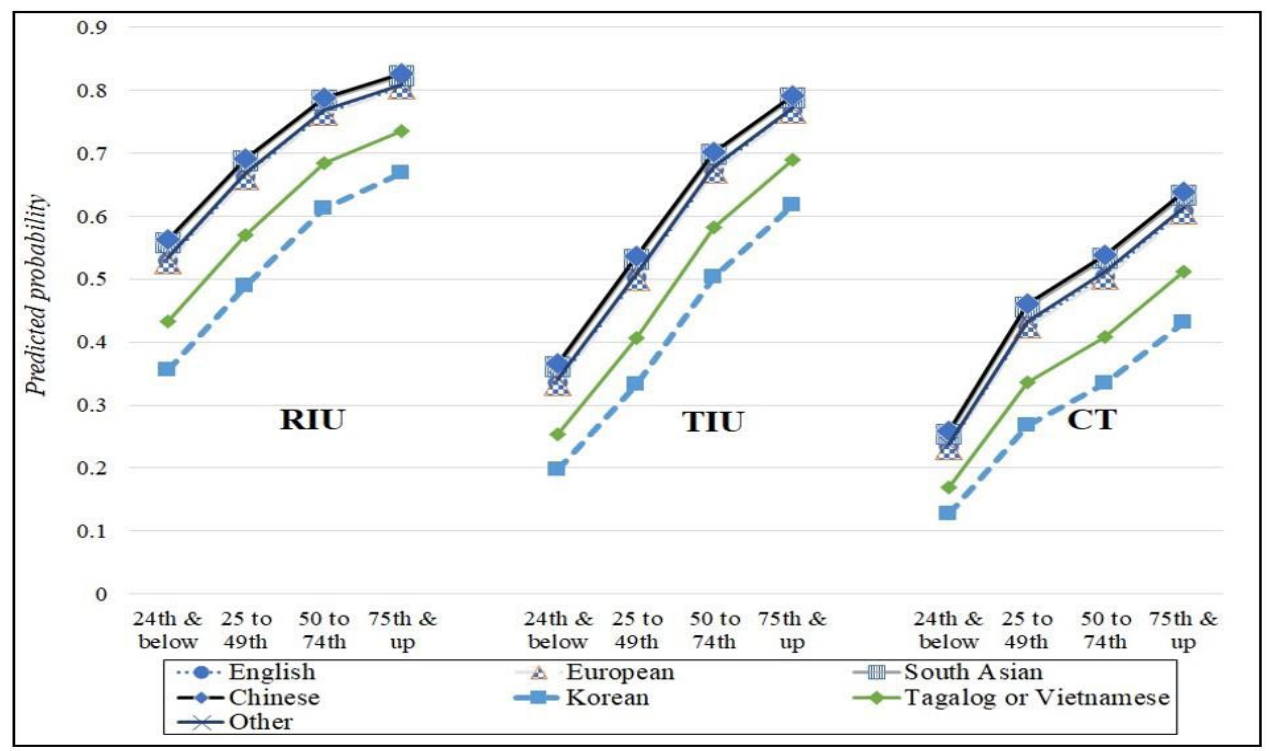

Figure 4. Predicted probability of degree completion by HS-GPA, ethno-linguistic group and institutional type at entry 
Degree completion probabilities do, however, vary by language group across institutional types and HSGPA percentile ranges. Chinese and South Asian students with lower HSGPA's (24th percentile and below) who entered an RIU have considerably higher probabilities of graduating than those who entered a TIU who in turn perform better than those who initially enrolled in a CT program. For high achieving students (75th percentile and above) in these same ethno-linguistic groups the likelihood of degree completion is highest among RIU entrants. The difference between RIU and CT completions for these groups is particularly pronounced. Completion probabilities for English, European, and Other Language speakers follow a similar pattern across institutional types and HSGPA ranges. By contrast, Korean and Vietnamese /Tagalog speakers consistently lag the predicted performance of other ethno-linguistic groups irrespective of HSGPA or whether they initially enrolled in an RIU, TIU, or CT.

\section{Discussion}

The main findings from our analyses suggest, first, that institutional stratification guides pathway admissions and, in combination with HSGPA, is instrumental in degree completion. Secondly, there is considerable variation in degree completion across ethno-linguistic groups, irrespective of pathway choice (i.e., institutional type at entry) or HSGPA. With respect to pathways, our results indicate lower predicted completion rates for TIU and CT students compared to RIU students. The lower completion predictions for these pathways raises both equity and administrative issues. The first of these is whether and how TIU and CT students differ from those entering an RIU (Davies, 2005; Stephan, Rosenbaum, \& Person, 2009). Prior research demonstrates that CT students in particular face barriers to completion, such as family and work responsibilities (Andres, Adamuti-Trache, Yoon, Pidgeon \& Thomsen, 2007). Additionally, CT students may encounter logistical challenges when transferring from a two-year college to a four-year university program. Although such pathway transfers are coordinated with the aim of minimizing time to graduation (Heslop, 2015), they remain an added complication in the timely progression to degree completion.

The probability of degree completion rises in relation to HSGPA across all pathways in a hierarchical system (Kelly \& Schneider, 2012). However, our more detailed analysis of different HSGPA levels illustrates particular benefits to gaining admission to an RIU. Completion probabilities at RIUs are greater not only for high-performing students but also for those with comparatively low HSGPAs. Conversely, students with higher HSGPA's who enter a TIU or CT are less likely to graduate with a BA/BSc than students with lower HSGPA's who attend an RIU. Although academic selectivity supports and reinforces student-institution match, these anomalous cases of 'overmatch' (low HSGPA - high selectivity) and 'undermatch' (high HSGPA - low selectivity) further demonstrate how accessing more selective institutions promotes degree completion (Dillon \& Smith, 2015).

Our results show marked differences in the probability of degree completion by ethno-linguistic status-principally among Asian language students who make up the majority of non-English speakers in BC's post-secondary system. Although Chinese language speakers have higher completion rates overall, this difference is largely explained in the model that accounts for institution at entry. By contrast, the non-completion rate for Korean and Tagalog/Vietnamese language speakers increases once the model accounts for this factor.

This variability necessarily raises questions about the factors that underlie academic success for some ethno-linguistic groups but not others. Previous research highlights the importance of students' preparation during the K-12 school period and in Canada this has generated discussion and debate about cultural stereotypes and the effectiveness of ethnic capital in preparing students for competitive PSE entry (Gilmour, Bhandar, Heer, \& Ma, 2010). Other research attempts to counter stereotypes of Asian exceptionalism by reframing analyses to reflect educational contexts as experienced by students of different ethnicities (Cui, 2015; Poon, Squire, Kodama \& Byrd, 2016). Our analysis of the varied trajectories of ethno-linguistic groups enrolled in a stratified PSE system emphasizes the linkages between high school achievement, undergraduate admissions, and graduation. In doing so we draw attention to the institutional complexities encountered by students of diverse ethnicities as they pursue a bachelor's degree.

\section{Limitations and Future Research}

Our research is constrained by several factors. First, the findings do not generalize beyond British Columbia. Other jurisdictions have different structures and policies that uniquely shape their students' experiences and out- 
comes. Secondly, the provincial administrative data we employ enables a detailed tracking of educational trajectories but lacks the personal information needed to adequately describe students' social relations as well as their subjective understanding of the university experience. Additionally, these data limit our ability to fully define key variables. For example, ethno-linguistic categories merge multiple regional languages. Also, home language is but one proxy for ethnicity. Information on students' race, ethnic status and, in the case of immigrants, their country of origin remain largely absent from government data (Robson, 2018). Given the current ethnic composition of Canadian campuses and projected immigration flows, greater attention to the collection and use of race-ethnicity data would facilitate future analyses of equity and inclusion in diverse and increasingly stratified provincial PSE systems (Zarifa, 2012).

It is also important to note that the various vertical and horizontal structures of Canadian PSE may not be adequately represented by the typologies we employ in this paper. However, the application of a more finely graduated institutional scheme requires larger and broader institutional samples available only at the national level. As well, different field of study categorizations may yield different results (Graham, Frederick, Byars-Winston, Hunter, \& Handelsman, 2013; Iannelli, Gamoran \& Patterson, 2018). Again, these distinctions could be better examined with more comprehensive institutional and student samples.

Degree completion is only one of many milestones students reach in the course of their educational careers (Andres, 2015). Our research has examined PSE admissions and degree completion and demonstrated the linkages between these transitions and an individual's early academic achievement. Analyses of different outcomes would provide additional insight into the effects of institutional stratification and ethnicity. For example, how transitions to the labour market differ at the intersection of institution attended and ethno-linguistic status would be an important extension to consider in future research (Betts, Ferrall \& Finnie, 2013; Lessard-Phillips, Boliver, Pampaka \& Swain, 2018).

\section{Acknowledgements}

The authors wish to acknowledge support received from the Social Sciences and Humanities Research Council (435-2014-1274) and the BC Student Transitions Project.

\section{References}

Abada, T., Hou, F., \& Ram, B. (2009). Ethnic differences in educational attainment among the children of Canadian immigrants. Canadian Journal of Sociology, 34(1), 1-30.

Andres, L. (2015). A look back: A retrospective analysis of the sequence of life course events over 22 years. BC Council on Admissions and Transfer. Retrieved January 2019, from: http://www.bccat.ca/pubs/ ALookBack report Jan2015.pdf

Andres, L., \& Adamuti-Trache, M. (2007). You've come a long way, baby? Persistent gender inequality in university enrolment and completion in Canada, 1979-2004. Canadian Public Policy, 33(1), 93-116.

Andres, L., Adamuti-Trache, M., Yoon, E.-S., Pidgeon, M., \& Thomsen, J. P. (2007). Educational expectations, parental social class, gender and postsecondary attainment: A 10-year perspective. Youth $\&$ Society, 39(2), 135-163.

Arida, A. (2013). In pursuit of the 'right' student: A case study in assessing the effectiveness of enrollment management in shaping a first-year class. Unpublished Master's Thesis, Department of Educational Studies, The University of British Columbia, Vancouver, BC.

Barr-Telford, L., Cartwright, F., Prasil, S., \& Shimmons, K. (2003). Access, persistence and financing: First results from the Postsecondary Education Participation Survey (PEPS). Statistics Canada, Education Skills and Learning-Research Papers, Catalogue No. 81-595-MIE - No. 7.

Betts, J., Ferrall, C., \& Finnie, R. (2013). The role of university characteristics in determining post-graduation outcomes: Panel evidence from three Canadian cohorts. Canadian Public Policy, 39, S81-S106.

Bornstein, M. H. (2012). Cultural approaches to parenting. Parenting: Science and Practice, 12(2-3), 212-221.

Card, D., Payne, A., \& Sechel, C. (2011). Understanding the gender gap in university participation: An exploration of the application behaviour on Ontario high school students. Toronto: Higher Education Quality Council of Ontario. 
Caro, D., McDonald, J., \& Willms, D. (2009). Socio-economic status and academic achievement trajectories from childhood to adolescence. Canadian Journal of Education, 32(3), 558-590.

Childs, S., Finnie, R., \& Martinello, F. (2017). Postsecondary student persistence and pathways: Evidence from the YITS-A in Canada. Research in Higher Education, 58(3), 270-294

Christofides, L., Hoy, M., Milla, J. \& Stengos, T. (2015). Grades, aspirations, and postsecondary education outcomes. Canadian Journal of Higher Education, 45(1), 48-82.

Chua, A. (2011). Battle hymn of the tiger mother. New York: Penguin.

Conrad, M., \& Morris, K. (2010). Shifting from retention rates to retention risk: An alternative approach for managing institutional student retention performance. Toronto: Higher Education Quality Council of Ontario.

Costigan, C., Hua, J., \& Su, T. (2010). Living up to expectations: The strengths and challenges experienced by Chinese Canadian students. Canadian Journal of School Psychology, 25(3), 223-45.

Cowin, B. (2013). Student transfer, success, and mobility in $\mathrm{BC}$ post-secondary institutions, a synthesis of research. Vancouver, BC: British Columbia Council on Admissions and Transfer.

Crul, M., Keskiner, E., \& Lelie, F. (2017) The upcoming new elite among children of immigrants: $A$ cross-country and cross-sector comparison. Ethnic and Racial Studies, 40(2), 209-229.

Cui, D. (2015). Capital, distinction, and racialized habitus: Immigrant youth in the educational field. Journal of Youth Studies, 18(9), 1154-1169.

Cui, D., \& Kelly, J. (2013). Too Asian? Or the invisible citizen on the other side of the nation? Journal of International Migration and Integration, 14(1), 157-174.

Davies, S. (2005). A revolution of expectations? Three key trends in the SAEP data. In R. Sweet \& P. Anisef (Eds.), Preparing for post-secondary education: New roles for governments and families (pp.
149-165). Montreal, QC: McGill-Queen's University Press.

Davies, S., Maldonado, V., \& Zarifa, D. (2014). Effectively maintaining inequality in Toronto: Predicting university destinations of Toronto District School Board graduates. Canadian Review of Sociology, 51(1), 22-53.

Davies, S., \& Zarifa, D. (2012). The stratification of universities: Structural inequality in Canada and the United States. Research in Social Stratification and Mobility, 30(2), 143-158.

Dillon, E., \& Smith, J. (2015). The consequences of academic match between students and colleges. Discussion Paper No. 9080. Bonn: Institute for the Study of Labour (IZA).

Dooley, M., Payne, A., \& Robb, L. (2012) . Persistence and academic success in university. Canadian Public Policy, 38(3), 315-339.

Finnie, R., \& Usher, A. (2005). Measuring the quality of post-secondary education: Concepts, current practices and a strategic plan. Research Report W|28, Canadian Policy Research Networks Inc. (CPRN), Ottawa: ON.

Finnie, R., \& Qiu, H. (2008). Is the glass (or classroom) half empty or nearly full? New evidence on persistence in post-secondary education in Canada. In R. Finnie, R. Mueller, A. Sweetman, \& A. Usher (Eds.), Who goes? Who stays? What matters? Accessing and persisting in post-secondary education in Canada (pp. 179-208). Montreal: McGill-Queen's University Press.

Finnie, R., Mueller, R., Sweetman, A., \& Usher, A. (2008). Who goes? Who stays? What matters? Accessing and persisting in post-secondary education in Canada. Montreal, QC: McGill-Queen's University Press.

Finnie, R., Childs, S., \& Qui, T. (2012). Patterns of persistence in post-secondary education in Canada: New evidence for Ontario. Toronto, ONT: Higher Education Quality Council of Ontario.

Fisher, D., Rubenson, K., Lee, J., Clift, R., Maclvor, M., \& Meredith, J. (2014). The transformation of the PSE system in British Columbia. In D. Fisher, 
K. Rubenson, T. Shanahan, \& C. Trottier (Eds.), The development of post-secondary education systems in Canada (pp. 35-121). Montreal, QC: McGill-Queen's University Press.

Frey, W. (2014). The diversity explosion: How new racial demographics are remaking America. Washington, DC: Brookings Institution Press.

Gilmour, R., Bhandar, D., Heer, J., \& Ma, M. (2012). "Too Asian?" Racism, privilege, and post-secondary education. Toronto, ON: Between the Lines.

Goodman, J., Hurwitz, M., \& Smith, J. (2015). Access to four-year public colleges and degree completion. Working paper 20996. Cambridge, MA: National Bureau of Economic Research. Retrieved January 2019, from: http://www.nber.org/papers/w20996

Graham, M., Frederick, J., Byars-Winston, A., Hunter, A., \& Handelsman, J. (2013). Increasing persistence of college students in STEM. Science, 341(6153), 1455-1456.

Hallsten, M., \& Thaning, M. (2018). Multiple dimensions of social background and horizontal educational attainment in Sweden. Research in Social Stratification and Mobility, 56, 40-52.

Hernán, M. A., \& Robins J. M. (2018). Causal inference. Boca Raton: Chapman \& Hall/CRC. Retrieved from: https://www.hsph.harvard.edu/miguel-hernan/causal-inference-book/

Heslop, J. (2015). B.C. Bachelor degree completers of 2013/2014: A longitudinal research study from the Student Transitions Project. Victoria, BC: Ministry of Advanced Education, Skills and Training. Retrieved January 2019, from: https://www2.gov.bc.ca/assets/ gov/ education/post-secondary-education/data-research/stp/bach completers of 2013-2014 report v3 2015-10-07.pdf

Hiebert, D. (2015). Ethnocultural minority enclaves in Montreal, Toronto, and Vancouver. IRPP Study 52. Montreal: Institute for Research on Public Policy.

Horn, L. J., \& Zahn, L. (2001). From bachelor's degree to work: Major field of study and employment outcomes of 1992-93 bachelor's degree recipients who did not enroll in graduate education by 1997. Washington, DC: National Center for Education
Statistics.

Howell, J., Pender, M., \& Kumar, A. (2016). What can we learn from stated preferences, student actions and collegiate outcomes? In A. Kelly, J. Howell, $\&$ C. Sattin-Bajay (Eds.), Matching students to opportunity: Expanding college choice, access, and quality (pp. 33-52). Cambridge, MA: Harvard education Press.

Iannelli, C., Gamoran, A., \& Paterson, L. (2018). Fields of study: Horizontal or vertical differentiation within higher education sectors? Research in Social Stratification and Mobility, 57, 11-23.

Jiminez, T. (2017) The other side of assimilation: How immigrants are changing American life. Oakland, CA: University of California Press.

Jimenez, T., \& Horowitz, A. (2013). When white is just alright: How immigrants redefine achievement and reconfigure the ethno-racial hierarchy. American Sociological Review, 78(5), 849-871.

Kelly, A., \& Schneider, M. (2012). Getting to graduation: The completion agenda in higher education. Baltimore, MD: Johns Hopkins University Press.

Kelly, A., Howell, J., \& Sattin-Bajay, C. (2016). Matching students to opportunity: Expanding college choice, access, and quality. Cambridge, MA: Harvard Education Press.

Lambert, M., Zeman, K., \& Allen, M. (2004). Who pursues postsecondary education, who leaves and why: Results from the Youth in Transition Survey. Statistics Canada, Catalogue no. 81-595-MIE. Culture, Tourism and the Centre for Education Statistics - Research Papers, 2004026(6), 1-37.

Lee, J., \& Zhou, M. (2015). The Asian American achievement paradox. New York City, NY: Russell Sage Foundation.

Lehmann, W. (2014). Habitus transformation and hidden injuries: Successful working class university students. Sociology of Education, 87(1), 1-15.

Lessard-Phillips, L., Boliver, V., Pampaka, M., \& Swain, D. (2018). Exploring ethnic differences in post-university destinations of Russell Group graduates. Ethnicities, 18(4), 496-517. 
Ma, X., \& Frempong, G. (2013). Profiles of Canadian postsecondary education dropouts. Alberta Journal of Educational Research, 59(2), 141-161.

Ministry of Training, Colleges and Universities. (2015). Focus on outcomes, centre on students: Perspectives on evolving Ontario's university funding model. Toronto, Ontario. Retrieved January 2019, from: https://www.tcu.gov.on.ca/pepg/audiences/universities/uff/ UniversityFundingFormula

Motte, A., Qiu, H., \& Bussière, P. (2008). The Youth in Transition Survey: Following Canadian youth through time. In R. Finnie, R. E. Mueller, A. Sweetman, \& A. Usher (Eds.), Who goes? Who stays? What matters? Accessing and persisting in post-secondary education in Canada (pp. 63-75). Queen's Policy Studies Series. Montreal, QC and Kingston, ON: McGill-Queen's University Press.

Mueller, R. (2008). Access and persistence of students in Canadian post-secondary education: What we know, what we don't know, and why it matters. In R. Finnie, R. Mueller, A. Sweetman, \& A. Usher (Eds.). Who goes? Who stays? What matters? Accessing and persisting in post-secondary education in Canada (pp. 33-62). Montreal, QC and Kingston, ON: McGill-Queen's University Press.

Ng, F., \& Wang, Q. (2019). Asian and Asian-American parenting. In M. Bornstein (Ed.), Handbook of parenting, Vol. 4: Social conditions and applied parenting (pp. 108-169). New York City, NY: Routledge.

Parkin, A., \& Baldwin, N. (2009). Persistence in post-secondary education. In J. Berger, A. Parkin, S. Junor, and A. Motte (Eds.), The price of knowledge: Access and student finance in Canada (pp. 65-84). Montreal, QC: Canada Millennium Scholarship Foundation.

Poon, O., Squire, D., Kodama, C., \& Byrd, A. (2016). A critical review of the model minority myth in selected literature on Asian Americans and Pacific Islanders in higher education. Review of Educational Research, 86(2), 469-502.

Quadlin, N. (2017). Funding sources, family income, and fields of study in college. Social Forces, 96(1), 91-120.
Robson, K. (2018). Why won't Canada collect data on race and student success? The Conversation. Retrieved January 2019, from: https://theconversation. com/why-wont-canada-collect-data-on-race-andstudent-success-106689

Spector, P. E., \& Brannick, M. T. (2011). Methodological urban legends: The misuse of statistical control variables. Organizational Research Methods, 14(2), 287-305.

Statistics Canada. (2015). Immigration and ethnocultural diversity in Canada. Retrieved January 2019, from https://www12.statcan.gc.ca/nhs-enm/2011/assa/99-010-x/99-010-x2011001-eng.cfm\#a2

Stephan, J., Rosenbaum, J., \& Person, A. (2009). Stratification in college entry and completion. Social Science Research, 38(3), 572-593.

Sweet, R., Robson, K., \& Adamuti-Trache, M. (2017). Ethnicity and effectively maintained inequality in B.C. universities. Canadian Review of Sociology, 54(4), 497-518.

Taylor, A., \& Krahn, H. (2013). Living through our children: Exploring the education and career 'choices' of racialized immigrant youth in Canada. Journal of Youth Studies, 16(8), 1000-1021.

Thiessen, V. (2009). The pursuit of post-secondary education: A comparison of First Nations, African, Asian, and European Canadian youth. Working Paper No. 19. Ottawa, ON/Vancouver, BC: Canadian Labour Market and Skills Researcher Network.

Warikoo, N. (2018). Race, ethnicity, and cultural processes in education: New approaches for new times. In J. Mehta \& S. Davies (Eds.), Education in a new society: Renewing the sociology of education (pp. 363-386). Chicago, IL: University of Chicago Press.

Wooldridge, J. M. (2016). Introductory econometrics: A modern approach (Sixth ed.). Boston, MA: Cengage Learning.

Zarifa, D. (2012). Choosing fields in an expansionary era: Comparing two cohorts of baccalaureate degree-holders in the United States and Canada. Research in Social Stratification and Mobility, 30(3), 328-351. 
Zhou M., \& Kim S. (2006). Community forces, social capital, and educational achievement: The case of supplementary education in the Chinese and Korean immigrant communities. Harvard Education Review, 76(1),1-29

\section{Contact Information}

Robert Sweet

rasweet@lakeheadu.ca

\section{Notes}

1 Importantly, many students who are identified as non-completers within our study are likely to go on to complete a degree. As Heslop (2015) notes, the median time for degree completion is 5.7 years in $\mathrm{BC}$ and this length of time increases with the number of institutions a student attends and the number of credentials earned prior to degree completion.

2 The RIU, TIU, and CT categories typify various university programs in BC and represent the PSE 'pathways' students choose in pursuit of a degree. While all such pathways involve a 4 year baccalaureate program of study and may involve transfer across categories, we consider only the institution at which the student was initially registered or the 'institution at entry'.

3 These control variables also offer insight into other important socio-demographic factors that are related to completion. However, the results section does not interpret them as the analysis has not been designed with the intent of examining these group differences. Following Spector and Brannick (2011), we believe that "attention to demographics should focus on mechanisms that explain relations with demographics rather than on the demographics themselves" ( $p$. 297). Thus, it will be necessary for future studies to have an explicit focus on other group differences in relation to PSE outcomes.

4 The BC Ministry of Education assigns a median family income value to each school, a measure that matches household income from the 2001 and 2006 Census to all students' home postal codes. Following Caro, McDonald and Willms (2009), this information was used to construct a derived income variable representing the average school-level income across all schools attended by the student. The resulting variable is used in the analysis to approximate the socio-economic status of a student's family. A limitation of this approximation is that school catchment areas can be large and/or diverse and thus contain households with very different socio-economic characteristics.

5 The typology was constructed with reference to previous work by Horn and Zahn (2001) and Quadlin (2017) to differentiate between work-orientated fields of study within STEM and non-STEM fields. The STEM applied category includes engineering, computer science, natural resources, kinesiology, health-related disciplines. The STEM academic category includes math, physical sciences, biology, and cognitive science. The non-STEM applied category includes communications, business, education, law, and social work. The non-STEM academic category includes English and languages, liberal and fine arts, history, philosophy, and social sciences. 


\section{Appendix 1. Descriptive Statistics}

\begin{tabular}{|c|c|c|}
\hline Variables & $N$ & $\begin{array}{c}\text { Proportion who graduate with a } \\
\text { BA }\end{array}$ \\
\hline Total & 16795 & 0.601 \\
\hline \multicolumn{3}{|l|}{ Institutional type at entry } \\
\hline RIU & 9618 & 0.749 \\
\hline TIU & 4718 & 0.429 \\
\hline CT & 2459 & 0.354 \\
\hline \multicolumn{3}{|l|}{ Ethnolinguistic groups } \\
\hline English & 10463 & 0.563 \\
\hline European & 828 & 0.628 \\
\hline South Asian & 955 & 0.559 \\
\hline Chinese & 2946 & 0.756 \\
\hline Korean & 519 & 0.543 \\
\hline Tagalog/Vietnamese & 349 & 0.542 \\
\hline Other & 735 & 0.612 \\
\hline \multicolumn{3}{|l|}{ High-school GPA } \\
\hline 1-24 percentile & 4305 & 0.322 \\
\hline 25-49 percentile & 4246 & 0.563 \\
\hline 50-74 percentile & 4312 & 0.728 \\
\hline 75-99 percentile & 3932 & 0.809 \\
\hline \multicolumn{3}{|l|}{ Student characteristics } \\
\hline Male & 7236 & 0.561 \\
\hline Female & 9559 & 0.632 \\
\hline Non-Indigenous & 16248 & 0.610 \\
\hline Indigenous & 547 & 0.346 \\
\hline No past ESL training & 11483 & 0.571 \\
\hline Past ESL training & 5312 & 0.667 \\
\hline Metro Vancouver high school & 10078 & 0.653 \\
\hline Non-Metro Vancouver high school & 6717 & 0.524 \\
\hline \multicolumn{3}{|l|}{ Timing of BC K-12 entry } \\
\hline Primary & 13795 & 0.595 \\
\hline Elementary & 1333 & 0.623 \\
\hline Junior sec & 691 & 0.603 \\
\hline Senior sec & 976 & 0.660 \\
\hline
\end{tabular}




\begin{tabular}{lcc}
\hline Variables & N & $\begin{array}{c}\text { Proportion who graduate with a } \\
\text { BA }\end{array}$ \\
\hline FOS at PSE entry & & \\
Undeclared & 9814 & 0.560 \\
STEM applied & 1986 & 0.695 \\
STEM academic & 1227 & 0.635 \\
Non-STEM applied & 2062 & 0.705 \\
Non-STEM academic & 1706 & 0.579 \\
Timing of entry to PSE & & \\
Immediate & 13248 & 0.628 \\
1 year & 2474 & 0.469 \\
2 year & 1073 & 0.578 \\
\hline
\end{tabular}


Appendix 2. Institutional information and categorizations

\begin{tabular}{|c|c|c|c|c|}
\hline Name & RIU & TIU & CT & Low $n$ \\
\hline British Columbia Institute of Technology & & & * & \\
\hline Camosun College & & & * & \\
\hline Capilano University & & * & & \\
\hline College of New Caledonia & & & * & \\
\hline College of the Rockies & & & & $R$ \\
\hline Douglas College & & & $*$ & \\
\hline Emily Carr University of Art and Design & & * & & \\
\hline Kwantlen Polytechnic University & & ${ }^{*}$ & & \\
\hline Langara College & & & * & \\
\hline North Island College & & & $*$ & \\
\hline Northern Lights College & & & $*$ & \\
\hline Nicola Valley Institute of Technology & & & & $R$ \\
\hline Coast Mountain College & & & * & \\
\hline Okanagan College & & & * & \\
\hline Royal Roads University & & & & $R$ \\
\hline Selkirk College & & & * & \\
\hline Simon Fraser University & $*$ & & & \\
\hline Thompson Rivers University & & $*$ & & \\
\hline University of British Columbia & * & & & \\
\hline University of British Columbia Okanagan & * & & & \\
\hline Justice Institute of BC & & & & $R$ \\
\hline University of the Fraser Valley & & ${ }^{*}$ & & \\
\hline University of Northern British Columbia & * & & & \\
\hline University of Victoria & $*$ & & & \\
\hline Vancouver Community College & & & & $R$ \\
\hline Vancouver Island University & & $*$ & & \\
\hline
\end{tabular}

NOTE: " $r$ " denotes institutions removed from analysis. 